\title{
Ice velocity measurements of Langjökull, Iceland, from interferometric synthetic aperture radar (InSAR)
}

\author{
Steven PALMER, ${ }^{1}$ Andrew SHEPHERD, ${ }^{1}$ Helgi BJÖRNSSON, ${ }^{2}$ Finnur PÁLSSON ${ }^{2}$ \\ ${ }^{1}$ School of GeoSciences, University of Edinburgh, Drummond Street, Edinburgh EH8 9XP, UK \\ E-mail: s.j.palmer@sms.ed.ac.uk \\ ${ }^{2}$ Institute of Earth Sciences, Building of Natural Sciences, Askja, Sturlugata 7, IS-101 Reykjavík, Iceland
}

\begin{abstract}
We have computed the velocity of Langjökull ice cap (LIC), Iceland, using InSAR data acquired by the European Remote-sensing Satellite in 1994 and an ice-surface elevation model derived from a GPS survey conducted in 1997. The velocity map covers $68 \%$ of the $925 \mathrm{~km}^{2}$ of LIC. Eight principal outlet glaciers were identified, along which ice velocities increased from zero at the ice divide to a maximum of $75 \mathrm{~m} \mathrm{a}^{-1}$. When the InSAR velocity dataset is compared with surface GPS measurements of ice flow determined in summer 2001, there is generally good agreement, suggesting interannual and seasonal stability for much of the ice cap during this period. However, non-zero ice velocities at the termini of four of the eight glaciers surveyed suggest that these glaciers were advancing in 1994. Comparison of our GPS and InSAR velocities suggests that Sudurjökull experienced elevated velocity in late February 1994, which, when other studies are considered, appears to be consistent with a glacier surge.
\end{abstract}

\section{INTRODUCTION}

At the end of the 20th century, the mass loss of glaciers and ice caps (excluding those of Antarctica and Greenland) is estimated to have formed the largest cryospheric component of the observed sea-level rise of $3.1 \pm 0.7 \mathrm{~mm} \mathrm{a}^{-1}$ (Lemke and others, 2007). Estimates of the 21st-century sea-level contribution due to glaciers and ice caps vary by a factor of two (Van de Wal and Wild, 2001; Raper and Braithwaite, 2006; Meehl and others 2007) depending on how the sensitivity of ice mass balance to future climate forcing is modelled. Because ice velocity is a factor in the estimation of glacier mass balance, knowledge of its seasonal and interannual variability is important to gain an improved understanding of the response of glaciers and ice caps to expected climate change.

About $11 \%\left(11200 \mathrm{~km}^{2}\right)$ of Iceland is covered by temperate ice (Fig. 1), comprising roughly $4 \%$ of the $272200 \mathrm{~km}^{2}$ of Arctic land ice outside of Greenland (Dowdeswell and others, 1997). In the maritime Icelandic climate, snow accumulation is sensitive to winter temperature and the position of the paths of the North Atlantic lowpressure weather fronts. As a consequence, the temperate glaciers of Iceland are dynamically active and respond sensitively to climatic fluctuations (Björnsson, 1979). On the highest parts of the main ice caps, average annual temperatures are below freezing. Due to a steeply decreasing precipitation gradient from south to north, south-flowing glaciers tend to be steep and fast-flowing, terminating at low altitude in areas of high ablation. Conversely, north-flowing glaciers have lower accumulation in their higher reaches, shallower slopes and terminate in broad fronts at higher altitudes. During the early 20th century, there was a general recession of Icelandic glaciers which accelerated after the 1930s and slowed after the 1960s (Björnsson, 1979).

With an area of $925 \mathrm{~km}^{2}$, Langjökull is Iceland's second largest ice cap (Björnsson and Pálsson, 2008). Radio-echo sounding has revealed a mean ice thickness of about $200 \mathrm{~m}$ and a maximum of $580 \mathrm{~m}$ (Björnsson and others, 2006). Total ice volume is estimated to be $195 \mathrm{~km}^{3}$, which is equivalent to $0.5 \mathrm{~mm}$ of eustatic sea-level rise (SLR). The southern outlet glacier of Hagafellsjökull Vestri flows down to an altitude of $500 \mathrm{~m}$ and, following at least 40 years of quiescence, has experienced four separate periods of glacier surging between 1971 and 2002 affecting an area of $150 \mathrm{~km}^{2}$ (Björnsson and others, 2003). The surface mass balance of Langjökull ice cap (LIC) has been measured at 22 stake locations since 1996. The net surface mass balance was negative from 1996 to 2001, resulting in a loss of $5.36 \mathrm{~km}^{3}$ of ice or $3 \%$ of the total ice-cap mass. Although there is no simple relationship to explain the observed mass loss, the minimum winter surface mass balance in 2001 coincided with a precipitation minimum recorded at a nearby meteorological station (Hveravellir), and, in consequence, it would appear to have meteorological origins (Björnsson and others, 2002).

In this study, we use interferometric synthetic aperture radar (InSAR) to determine the velocity of LIC in 1994, and ground-based global positioning system (GPS) observations made in 2001 to investigate the extent to which velocity fluctuations may be responsible for recent mass trends.

\section{METHODS}

A repeat-pass interferogram calculated from synthetic aperture radar (SAR) data records surface motion within the data repeat interval (Goldstein and others, 1993). If the perpendicular component of distance between sensor positions of the repeat-pass data is non-zero, there is an additional topographic contribution to the interferometric phase which can be removed to isolate the motion contribution (Kwok and Fahnestock, 1996). A single interferogram measures only the component of motion in the satellite line of sight (LOS), orthogonal to the flight path. To estimate surface motion in three dimensions, interferograms from ascending and descending satellite orbits can be combined with the additional assumption of ice motion parallel to the ice surface (Joughin and others, 1998). In general, ice does not flow parallel to the surface; instead, ice flow is inclined slightly upwards in the ablation zone and slightly downwards in the accumulation zone (Paterson, 1994). For LIC, where slopes are low and both accumulation and ablation are modest, the assumption of surface-parallel flow should 


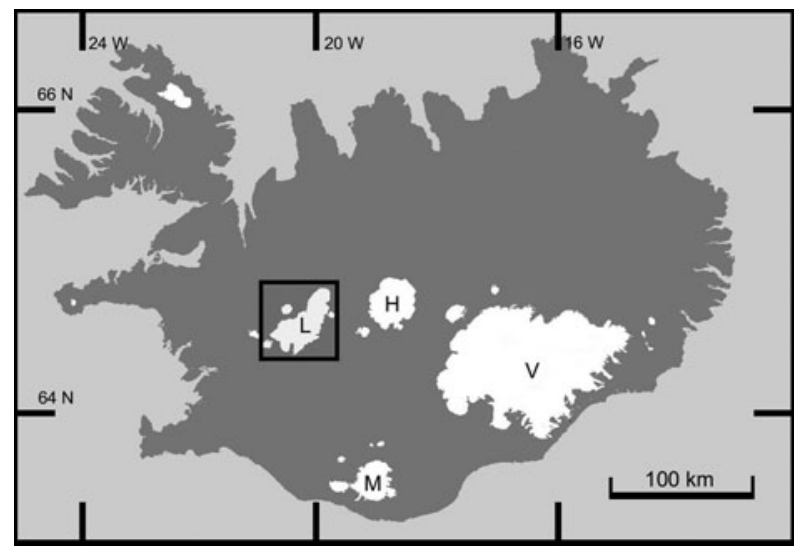

Fig. 1. Location of Langjökull and other major ice caps in Iceland.

not yield significant errors in estimates of vertical motion. Estimates of horizontal components of motion should be relatively unaffected by deviations from surface-parallel flow because the SAR look direction is close to nadir $\left(\sim 24^{\circ}\right)$ and because surface gradients of LIC are low. In the absence of SAR data acquired from separate orbits, the ice-flow direction can be estimated from the direction of maximum averaged (over an area with a radius of 10-20 times the ice thickness) downhill slope (Paterson, 1994).

Repeat-pass interferograms were derived from pairs of European Remote-sensing Satellite-1 (ERS-1) SAR images obtained from satellite passes sequentially 3 days apart in late February 1994 (Table 1). Data were acquired from both ascending and descending satellite orbits, providing InSAR data oriented in approximately orthogonal directions. The SAR scenes were co-registered to sub-pixel accuracy using a cross-correlation of the detected single-look complex data (Wegmüller and others, 1998). We removed the 'flat-Earth' component arising from the Earth's curvature using precise orbit information (Scharroo and Visser, 1998). The phase contribution due to topography was removed by subtracting a synthetic interferogram (Massonnet and Rabaute, 1993) generated from a digital elevation model (DEM) of LIC. This external DEM was constructed from a GPS survey conducted in April 1997, with values in the horizontal axes equally spaced every $200 \mathrm{~m}$ and an estimated vertical accuracy of 2-5 m. After accounting for these topographic signals, the phase due to motion during the repeat-pass interval was unwrapped (Wegmüller and others, 1998) and from this we generated ice displacement maps in both ascending and descending geometries.

LIC displacement maps formed from InSAR data acquired in ascending and descending satellite orbits were then combined with the surface DEM to derive a three-dimensional (3-D) surface-parallel ice velocity vector field for about $50 \%$ of the ice cap (Fig. 2). Ice velocity errors in areas with dual-look InSAR coverage were about $5 \mathrm{~m} \mathrm{a}^{-1}$ as estimated from the range of ice velocity values measured for stationary bedrock (root-mean-square (rms) value is $4.5 \mathrm{~m} \mathrm{a}^{-1}$ ). However, to improve spatial coverage we augmented the 3-D velocity field with estimates of ice motion derived from single-look InSAR displacement fields in other areas, excluding data for which the angle between sensor look direction and local aspect was $>72^{\circ}$. This procedure introduced an additional error due to uncertainties in the ice-flow direction, which we estimate to be $\pm 5^{\circ}$. As the southern part of LIC was not covered by ascending-pass data,
Table 1. ERS SAR data used in our study

\begin{tabular}{lcccc}
\hline $\begin{array}{l}\text { Satellite } \\
\text { heading }\end{array}$ & Image dates & $\begin{array}{c}\text { Satellite } \\
\text { orbits }\end{array}$ & $\begin{array}{c}\text { Interferogram } \\
\text { perpendicular } \\
\text { baseline }\end{array}$ & $\begin{array}{c}\text { Interferogram } \\
\text { temporal } \\
\text { baseline } \\
\text { days }\end{array}$ \\
\hline \multirow{2}{*}{ Descending } & 22 Feb 1994 & 13625 & 140 & 3 \\
& 25 Feb 1994 & 13668 & & 3 \\
Ascending & 24 Feb 1994 & 13660 & 80 & 3 \\
& 27 Feb 1994 & 13703 & & \\
\hline
\end{tabular}

ice velocities were calculated in that location using descending-pass data only and we estimate errors for this area to be $\sim 10 \mathrm{~m} \mathrm{a}^{-1}$ as estimated in the same way as the dual-look error ( $r m s$ value is $8.8 \mathrm{~m} \mathrm{a}^{-1}$ ). The sensor LOS for ascending passes is almost perpendicular to the direction of ice flow, and is therefore insensitive to ice motion at the south-flowing glaciers in the southern part of the ice cap.

Finally, ice motion was determined at 22 stakes positioned across LIC (Fig. 2) during the summer of 2001 (April to October) over a period of 170 days using differential GPS. The error on the stake velocities was calculated by dividing the sum of the error in the position of the differential GPS measurements $(2 \times 50 \mathrm{~cm})$ by the interval between measurements ( 170 days) to obtain a value of $\pm 2.2 \mathrm{~m} \mathrm{a}^{-1}$.

\section{RESULTS AND DISCUSSION}

Our InSAR data represent the first detailed map of the LIC velocity field (Fig. 2). Eight outlet glaciers are apparent from the InSAR velocity data, with the majority located in the northern half of LIC. Three glaciers flow to the west or northwest and the remainder flow to the east or southeast. Although apparent from GPS measurements (locations 1-8, Fig. 2), the southward-flowing outlet glacier of Hagafellsjökull Vestri is not obvious in the InSAR data due to the large angle between the ice-flow direction and the radar look direction, a condition that is not favourable for detecting ice motion from single-pass data. These eight glaciers surveyed range in area from 18 to $71 \mathrm{~km}^{2}$ (Table 2), and the maximum ice speed we have recorded is $75 \mathrm{ma}^{-1}$ at the terminus of Sudurjökull in the southeast part of LIC. Derived velocities are below the InSAR measurement error for $32 \%$ of $\mathrm{LIC}$ and are omitted from Figure 2. The elevation at which the surveyed glaciers reach their maximum velocity varies between $1200 \mathrm{~m}$ for the northeast glacier to $870 \mathrm{~m}$ for Kirkjujökull, with an average across all eight outlet glaciers of $1000 \mathrm{~m}$.

We extracted InSAR velocity data along eight transects (see Fig. 2) of LIC that passed close to the centre of each principal glacier and were linked by the GPS survey sites, to allow for a more detailed comparison of the two datasets. A summary of LIC geometry and flow along each transect is shown in Table 2. The glaciers can be grouped by the shape of their InSAR velocity profiles as shown in Figure 3. Along the northwest and northeast profiles, ice velocity increases progressively from near-zero at the highest elevations to a maximum about $2.5 \mathrm{~km}$ from the ice margin at an elevation of about $1150 \mathrm{~m}$, and decreases gradually thereafter to about zero at the terminus. The southwest transect has similar characteristics, although, due to loss of coherence near the ice margin, InSAR velocity was not retrievable for the whole 


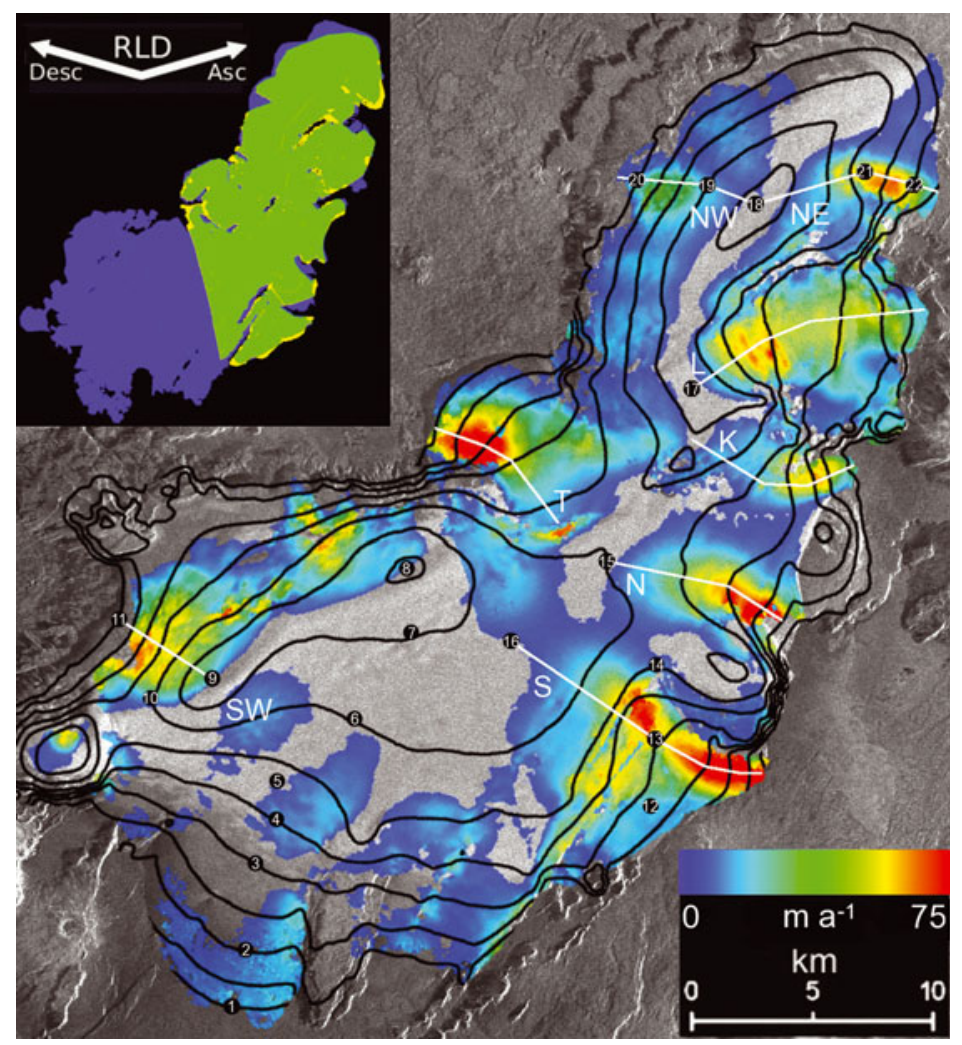

Fig. 2. Ice velocity map with $100 \mathrm{~m}$ elevation contours, GPS stake locations and data transects shown in Figures 3 and 4 , projected over SAR intensity image. Locations of data transects are shown in white: northwest transect (NW), northeast transect (NE), Leidarjökull (L), Kirkjujökull (K), Nordurjökull (N), Sudurjökull (S), southwest transect (SW), Thristapajökull (T). Areas of 3-D velocity (green), ascending pass only (yellow) and descending pass only (blue) are shown in the inset. Radar look direction (RLD) for ascending (Asc) and descending passes (Desc) is also shown.

profile. Although Kirkjujökull exhibits a similar profile, ice velocity at the terminus is about $20 \mathrm{~m} \mathrm{a}^{-1}$. At Thristapajökull, the ice velocity increases along the transect until it reaches its maximum value of $75 \mathrm{~m} \mathrm{a}^{-1}$ about $3 \mathrm{~km}$ from the margin. Below this, ice velocity decreases with a roughly constant rate to about $30 \mathrm{ma}^{-1}$ at the ice margin.

The three remaining transects exhibit markedly different behaviour from those above as well as each other (Fig. 3). Ice velocity for Leidarjökull increases rapidly from the ice divide to a maximum of $40 \mathrm{~m} \mathrm{a}^{-1}$ within a short distance $(4 \mathrm{~km})$ of the ice divide. Thereafter, it remains approximately constant at about $30 \mathrm{ma}^{-1}$ before decreasing to about $10 \mathrm{~m} \mathrm{a}^{-1}$ in the final $2 \mathrm{~km}$. The lower part of the outlet covers a caldera where ice thickness is $\sim 400 \mathrm{~m}$. The central part of the surface profile has a shallower surface gradient, and a rough estimate of the deformation velocity (from surface slope and ice thickness) yields $\sim 15 \mathrm{~m} \mathrm{a}^{-1}$, which accounts for only half of the observed surface flow. Calculations of basal water pressure based on radio-echo sounding studies of bedrock topography (Flowers and others, 2007; Guðmundsson and others, 2009) suggest that sliding at the bed is enhanced for Leidarjökull, which helps to explain the concave-up surface profile. At Nordurjökull, ice velocity increases at roughly a constant rate along the length of the profile, although, due to coherence loss near the terminus, we were unable to retrieve InSAR velocity for the final $1 \mathrm{~km}$. The lower slopes of this glacier are narrow and steep and the outlet flows into the Hvítárvatn lake. Though

Table 2. InSAR velocity transect attributes. Position and elevation of maximum speed are the distance from the margin $(\mathrm{km})$ and altitude $(\mathrm{m})$, respectively, at which maximum ice speed occurs

\begin{tabular}{|c|c|c|c|c|c|c|c|}
\hline \multirow[t]{2}{*}{ Transect } & Length & Maximum speed & Average speed & Average elevation & $\begin{array}{c}\text { Position of max. } \\
\text { speed }\end{array}$ & $\begin{array}{c}\text { Elevation of max. } \\
\text { speed }\end{array}$ & Glacier area \\
\hline & $\mathrm{km}$ & $\mathrm{ma}^{-1}$ & $\mathrm{ma}^{-1}$ & ma.s.l. & $\mathrm{km}$ & ma.s.l. & $\mathrm{km}^{2}$ \\
\hline Northwest & 7.0 & 25 & 14 & 1200 & 2.4 & 1100 & 18.5 \\
\hline Northeast & 9.0 & 44 & 22 & 1180 & 2.5 & 1200 & 18.3 \\
\hline Thristapajökull & 8.0 & 75 & 36 & 940 & 2.8 & 900 & 53.3 \\
\hline Leidarjökull & 12.0 & 37 & 25 & 1065 & 7.5 & 1100 & 71.2 \\
\hline Kirkjujökull & 7.5 & 38 & 20 & 1050 & 2.0 & 870 & 17.6 \\
\hline Nordurjökull & 10.0 & 64 & 28 & 1040 & 1.7 & 880 & 37.4 \\
\hline Southwest & 5.0 & 44 & 30 & 1125 & 1.5 & 1030 & 39.4 \\
\hline Sudurjökull & 13.5 & 63 & 34 & 980 & 4.8 & 890 & 61.3 \\
\hline
\end{tabular}



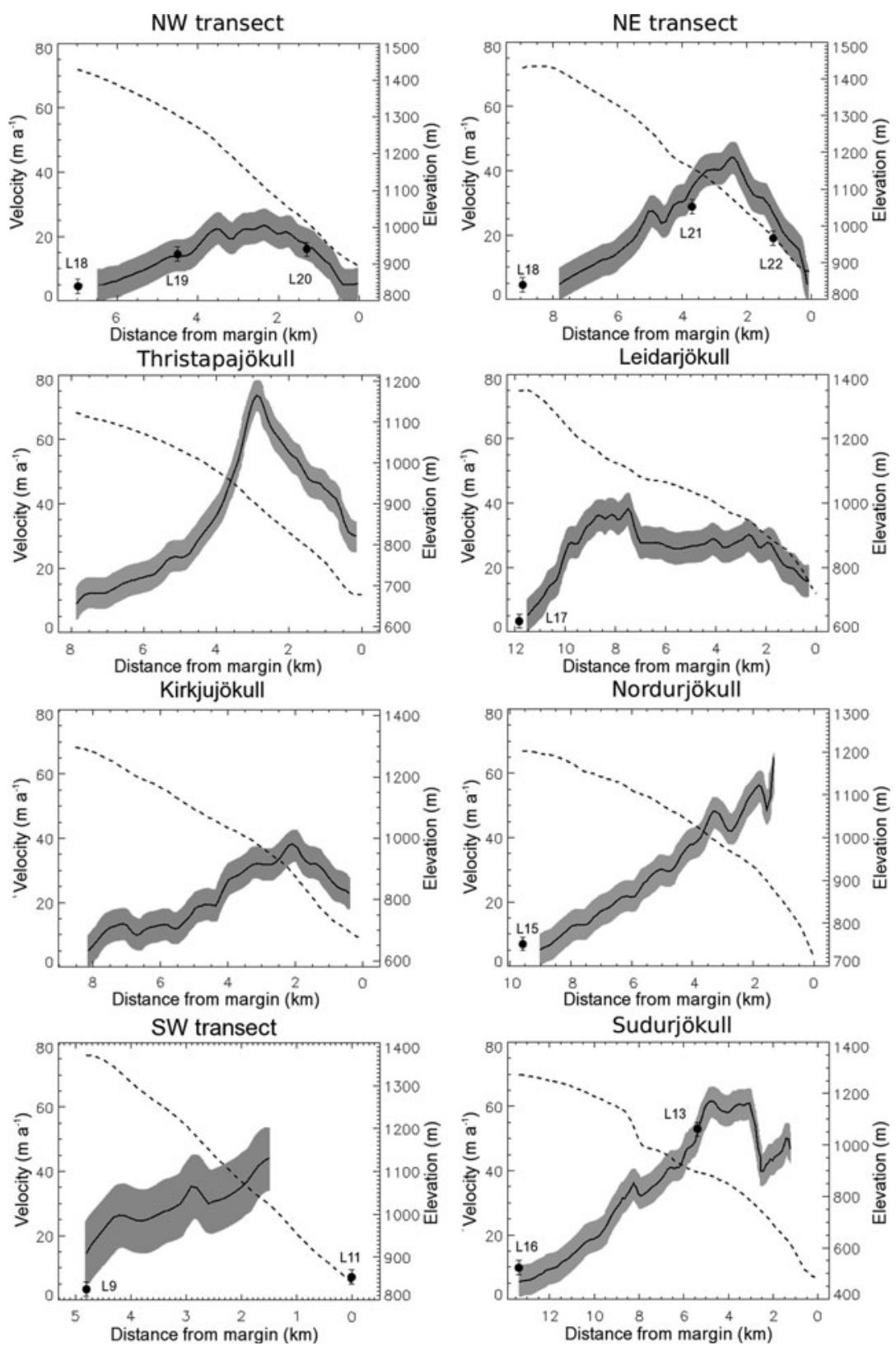

Fig. 3. InSAR-derived velocity for winter 1994 (solid curve) and 1997 ice surface (dashed curve) for transects shown in Figure 2. Solid points with error bars show 2001 summer velocity from stake measurements. Grey areas show error for InSAR velocity values.

the terminus does not float, ice breaks off at the margin into the lake, and the presence of water is likely to reduce basal friction, which may explain the high ice velocity near the terminus. Along Sudurjökull, ice velocity increases gradually downslope from the ice divide to about $60 \mathrm{ma}^{-1}$ where it remains roughly constant for $\sim 2 \mathrm{~km}$. At $3 \mathrm{~km}$ from the margin, ice velocity drops by $20 \mathrm{~m} \mathrm{a}^{-1}$ in $500 \mathrm{~m}$ horizontal distance; although low coherence prevented retrieval of the final $1 \mathrm{~km}$, it is likely that ice velocity at the terminus is about $40 \mathrm{ma}^{-1}$. This area of high velocity on the lower slopes suggests that in February 1994 Sudurjökull was experiencing a surge. The record of GPS-surveyed velocities at site L13 between summer 1997 and summer 2008 also suggests that another surge started in summer 1999 (the velocity in summer 1999 is $65 \mathrm{~m} \mathrm{a}^{-1}$ ) and culminated in 2004; by 2005 the velocity had dropped to $40 \mathrm{~m} \mathrm{a}^{-1}$. The positions of the terminus on maps from 1986, 1997 and 2004 show that the terminus must have advanced between 1986 and 1997 and again between 1997 and 2004, which is consistent with the above. There is anecdotal evidence that Sudurjökull has surged in the past (Björnsson and others, 2003) and it is also known from sediments in the lake in front of the terminus that Sudurjökull has been extremely dynamic (Geirsdóttir and others, 2008).

The correlation between the InSAR and GPS data, shown in Figure 4, is 0.79 with a rms difference of $5 \mathrm{~m} \mathrm{a}^{-1}$. Observations at locations on Hagafellsjökull Vestri were omitted, as ice flows in a direction for which the sensor had little sensitivity due to the acquisition geometry. In addition, the GPS data for this glacier show that, in 2001, the glacier velocity peaked $9.4 \mathrm{~km}$ from the margin at an elevation of $950 \mathrm{~m}$ and velocity was enhanced following a surge event of 1999, so agreement between the InSAR and GPS observations is not expected. That the smallest measurement uncertainties $\left( \pm 5 \mathrm{~m} \mathrm{a}^{-1}\right)$ are at the level of the rms difference between the InSAR and GPS velocities suggests that any seasonal or interannual variations in ice velocity between February1994 and summer 2001 are modest. 


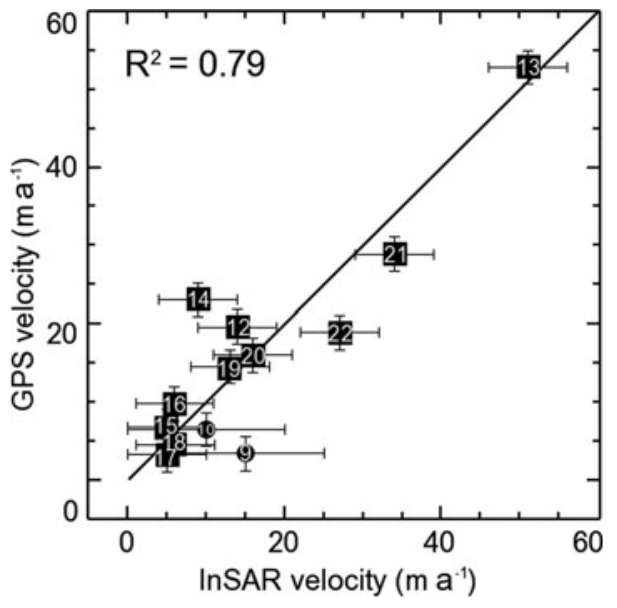

Fig. 4. Comparison of InSAR- and GPS-derived ice velocities for 13 locations on the ice cap, numbered as in Figure 2. Data from locations covered by dual-look InSAR are shown as squares; those for single-look coverage are shown as circles. Stake locations on Hagafellsjökull Vestri (1-8) are omitted - as agreement is not expected due to enhanced ice velocity in 2001 following a glacier surge in 1999 and the fact that the radar look direction is insensitive to flow. Location 11 was also omitted from the comparison, as no InSAR data were available within $500 \mathrm{~m}$.

\section{CONCLUSIONS}

This research provides the first ice velocity map for LIC. The velocity data were derived from ERS SAR interferometry and the data were acquired between 22 and 27 February 1994. We have identified eight principal outlet glaciers, and the maximum speed recorded was $75 \mathrm{~m} \mathrm{a}^{-1}$. Eight down-glacier velocity transects were extracted, along three of which we were able to compare our InSAR results with sparse surface velocity measurements determined from a GPS survey undertaken over 170 days during summer 2001. At six of the eleven locations included in both the GPS and InSAR datasets, ice velocity measurements were within error, indicating little change in ice velocity between February 1994 and summer 2001. The largest difference $\left(47 \pm 10 \mathrm{~m} \mathrm{a}^{-1}\right)$ between the InSAR and GPS velocity datasets occurred at Hagafellsjökull Vestri (L4) and is attributed to locally high InSAR measurement error and the fact that, in 2001, ice velocity was elevated following a surge.

The close agreement between the GPS and InSAR datasets indicates that seasonal ice velocity variations at LIC are small, though non-zero velocities at the termini of four of the eight glaciers surveyed suggest that these glaciers were advancing in February 1994. Our data, in addition to other studies, suggest that Sudurjökull was experiencing a surge in 1994.

\section{REFERENCES}

Björnsson, H. 1979. Glaciers in Iceland. Jökull, 29, 74-80.

Björnsson, H. and F. Pálsson. 2008. Icelandic glaciers. Jökull, 58, 365-386.

Björnsson, H., F. Pálsson and H. Haraldsson. 2002. Mass balance of Vatnajökull (1991-2001) and Langjökull (1996-2001), Iceland. Jökull, 51, 75-78.
Björnsson, H., F. Pálsson, O. Sigurðsson and G.E. Flowers. 2003. Surges of glaciers in Iceland. Ann. Glaciol., 36, 82-90.

Björnsson, H., S. Gudmundsson, T. Jóhannesson, F. Pálsson, G. Aðalgeirsdóttir and H. Haraldsson 2006. Geometry, mass balance and climate change response of Langjökull ice cap, Iceland. Obergurgl, International Arctic Science Committee. Working Group on Arctic Glaciology.

Dowdeswell, J.A. and 10 others. 1997. The mass balance of circum-Arctic glaciers and recent climate change. Quat. Res., $48(1), 1-14$.

Flowers, G.E., H. Björnsson, A. Geirsdóttir, G.H. Miller and G.K.C. Clarke. 2007. Glacier fluctuation and inferred climatology of Langjökull ice cap through the Little Ice Age. Quat. Sci. Rev., 26(19-21), 2337-2353.

Geirsdóttir, A., G.H. Miller, N.J. Wattrus, H. Björnsson and K. Thors. 2008. Stabilization of glaciers terminating in closed water bodies: evidence and broader implications. Geophys. Res. Lett., 35(17), L17502. (10.1029/2008GL034432.)

Goldstein, R.M., H. Engelhardt, B. Kamb and R.M. Frolich. 1993. Satellite radar interferometry for monitoring ice sheet motion: application to an Antarctic ice stream. Science, 262(5139), $1525-1530$.

Guðmundsson, S., H. Björnsson, G. Aðalgeirsdóttir, T. Jóhannesson, F. Pálsson and O. Sigurosson. 2009. Similarities and differences in the response of two ice caps in Iceland to climate warming. Hydrol. Res., 40(5), 495-502.

Joughin, I.R., R. Kwok and M.A. Fahnestock. 1998. Interferometric estimation of three-dimensional ice-flow using ascending and descending passes. IEEE Trans. Geosci. Remote Sens., 36(1), 25-37.

Kwok, R. and M.A. Fahnestock. 1996. Ice sheet motion and topography from radar interferometry. IEEE Trans. Geosci. Remote Sens., 34(1), 189-200.

Lemke, P. and 10 others. 2007. Observations: changes in snow, ice and frozen ground. In Solomon, S. and 7 others, eds. Climate change 2007: the physical science basis. Contribution of Working Group $I$ to the Fourth Assessment Report of the Intergovernmental Panel on Climate Change. Cambridge, etc., Cambridge University Press, 337-383.

Massonnet, D. and T. Rabaute. 1993. Radar interferometry: limits and potential. IEEE Trans. Geosci. Remote Sens., 31(2), 455-464.

Meehl, G.A. and 12 others. 2007. Global climate projections. In Solomon, S. and 7 others, eds. Climate change 2007: the physical science basis. Contribution of Working Group I to the Fourth Assessment Report of the Intergovernmental Panel on Climate Change. Cambridge, etc., Cambridge University Press, 747-845.

Paterson, W.S.B. 1994. The physics of glaciers. Third edition. Oxford, etc., Elsevier.

Raper, S.C.B. and R.J. Braithwaite. 2006. Low sea level rise projections from mountain glaciers and icecaps under global warming. Nature, 439(7074), 311-313.

Scharroo, R. and P. Visser. 1998. Precise orbit determination and gravity field improvement for the ERS satellites. J. Geophys. Res., 103(C4), 8113-8127.

Van de Wal, R.S.W. and M. Wild. 2001. Modelling the response of glaciers to climate change by applying volume-area scaling in combination with a high resolution GCM. Climate Dyn., 18(3-4), 359-366.

Wegmüller, U., C. Werner and T. Strozzi. 1998. SAR interferometric and differential interferometric processing chain. In Stein, T.I., ed. IGARSS '98. 18th International Geoscience and Remote Sensing Symposium, 6-10 July 1998, Seattle, Washington. Proceedings. Vol. 2. Piscataway, NJ, Institute of Electrical and Electronics Engineers, 1106-1108. 